\title{
孷水化物の拯取量と化学物質の代謝, 毒性
}

\section{一一低炭水化物食により肝菜物代謝醅素活性が增大}

医薬品, 農薬, 食品添加物, 工業薬品, 癌原性物質な ぞ多くの化学物質は, 生体内で代謝されて不活化（解毒 化）されたり，活性化（毒性化）されたりする．これら の代謝を触媒する酵素に薬物代謝酵素 (microsomal drug-metabolizing enzymes; mixed-function oxidase, microsomal hydroxylase あるいは microsomal monooxygenase とよばれている)がある.この酵素は主とし て肝，その中でもミクロソーム分画に最も多く存在す るが，肺や腎などにも存在する．薬物代謝酵素の活性は さまざまな環境因子の影響を受け易く，栄養状態もこの 因子の 1 つである.

栄養状態が肝薬物代謝酵素の活性に与兄る影響に関し ては，とくに蛋白質の多萓がこの酵素活性に影響を与兄 るといわれてきた，すなわち，高蛋白食はこの活性を上 昇させ，低蛋白食は低下させるという(1,2)。しかし，こ れらの報告を仔細に検討すると，高蛋白食は飼料中の炭 水化物を等量の蛋白質で，低蛋白食は蛋白質を等量の炭 水化物で置き換えることにより調製されている．したが って, 高蛋白食怕炭水化物食に, 低蛋白食嵪高炭水化 物食となっており，肝薬物代謝酵素の 活性を上昇（低 下）させたのは蛋白質の找取量の増加（減少）によるの か，炭水化物の摂取量の減少（増加）によるものか疑問 であった。

最近，筆者らは絶食によるラット肝薬物代謝酵素の活 性充進 ${ }^{(3)}$ を追求する過程で, 従来信じられてきた説と異 なり，炭水化物が肝薬物代謝酵素の活性を左右し，その ことが化学物質の毒性発現にも影響を与えるという重要 を知見を得た(4). 以下，その詳細を紹介するととすに， 化学物質の代謝拉よび毒性発現に括ける炭水化物の重要 性について述べたい。

肝薬物代謝酵素の活性（これはトルエン,トリクロロ エチンン, 四塩化炭素などの揮発性炭化水素の代謝速度 で測定されるが）は慨の摂取量が減少するにつれ，ほぼ 直線的に増大する．慨の摂取量か゚ 0（すなわち絶食）の ラットでは通常の給慨をうけたラットのほぼ $3 〜 4$ 倍の
活性を示す，一方，炭水化物の摂取量を一定に保つと， 蛋白質や脂肪は肝薬物代謝酵素の 活性に影響を与えな い，しかし，炭水化物の摂取量を変化させると，蛋白質 や脂肪の摂取量に関係なく，酔素活性は炭水化物の摂取 量の減少に伴い充進する。とくに，炭水化物を含まない 慨で飼育したラットは，たとえこの慨に栄盖学的に十分 な蛋白質や脂肪が含まれていても，絶食ラットとほ注等 しい活性立進を示す。これらの結果から，絶食による肝 薬物代謝酵素の活性光進は，慨の全体的なカロリー制限 というよりは，もしろ炭水化物からの摂取カロリーが制 限されたことに依存しているといえよう。このように， 肝薬物代謝酵素の活性は炭水化物の提取量に大きく支配 されており，蛋白質や脂肪の摂取量がこの酵素活性に与 える影響は炭水化物のそれに比較すると無視できる程度 に小さい.

さて，炭水化物の摄取量が肝薬物代謝酵素の活性を左 右することは明らかとなったが，このことが化学物質の 毒性にどのような影響をもたらすか興味が持たれる．四 塩化炭素はかつては広く用いられた塩素系有機溶剤であ るが，現在は毒性が強いためあまり用いられていない． むしろ実験室で溶媒として用いられる機会の注うが多い と思われる化学物質である。この四塩化炭素による肝障 害は母物質そのものによるのではなく，肝薬物代謝酵素 の触媒作用により反応性に富む活性代謝物 $\left(\cdot \mathrm{CCl}_{3}\right)$ に代 謝され，この代謝物が生体膜に結合することにより誘起 されるといわれている(1,5). したがって，四塩化炭素に よる肝障害の程度は肝薬物代謝酵素の活性とよい関連性 を持つことが知られており，炭水化物の摂取量に伴うこ の酵素活性の变動が化学物質の毒性発現に与兄る影響を 知るためには，四塩化炭素はよいモデル物質である．こ の四塩化炭素を炭水化物の含有量の異なった慨で飼育し たラットに与えると，GOT と GPT (それぞれ glutamic-oxaloacetic transaminase, glutamic-pyruvic transaminase の略. 肝細胞の障害時に血中に 遊出する酵素 である）值は炭水化物の揕取量の少ないラットほど上昇 
し, 肝障害が增強する.この傾向は形態学的にも同様に 認められ，炭水化物の摂取量の減少に伴い，肝中心性の 壊死が広範囲に認められるようになる。とくに炭水化物 を含まない慨で飼育されたラットでは，絶食ラットと同 程度のきわめて激しい肝障害が認められる。これらの結 果を総合すると，低炭水化物食は肝薬物代謝酵素の活性 を増大させ，四塩化炭素の代謝を兄進させて活性代謝物 の生成を増加させ，重篤な肝障害をひき起こすといえ る. すなわち，低炭水化物食が化学物質の代謝と毒性発 現に大きな役割を果たしていることが示唆される.

栄養が化学物質の毒性発現に与觉る影響は昔からの研 究テーマである. 先にも述べたよらに, 化学物質による 肝障害に関しては蛋白質の多寡がその毒性に大きな影響 を与えるといわれており，炭水化物の重要性を指摘した 報告はあまり見当らない，今までは，肝薬物代謝酵素の 活性は高蛋白食で亢進し，低蛋白食で低下するといわれ てきた、しかし，今までの実験における高蛋白食は低炭 水化物食であり，低蛋白食は高炭水化物食であるから， 低炭水化物食が肝薬物代謝酵素の活性を亢進させ, 高炭 水化物食は低下させるとるいえる．このように 考える と, 高蛋白食 (=低炭水化物食) が薬物代謝酵素の活性 を充進させるといら従来の報告は筆者らの知見と矛盾し ない.しかし，その内容は異なっている，筆者らの今ま での研究から，薬物代謝酵素の活性を支配している栄養 素は蛋白質でなく炭水化物であると考えたほうが妥当で あろら.今日まで, 炭水化物は単なるエネルギー源とし ての栄養素とみなされていたため，蛋白質の摂取量のみ 注目され, 同時に変動した炭水化物の役割には無関心で あったといえよう。
以上, 炭水化物の摂取量が化学物質の代謝と毒性に大 きな役割を果たすことを述べてきた。ラットのような小 動物から得られた結果をとトに外挿することは厳に慎重 でなければならないことはもちろんであるが，今，百歩 譲ってこの結果がヒトに適用できるとしよう．最近の日 本人の食生活は蛋白質や脂肪の摂取量が増加する反面, 穀物からの摂取カロリーは総掑取カロリーの $50 \%$ を下 まわり，穀物摂取の減少が著しい。この穀物摂取の減少 が四塩化炭素のような化学物質による急性毒性の発現ば かりでなく，長期的な化学物質の 摂取による 毒性発現 一とくに化学発癌物質による癌発生一に与える影響 を解明していくことが今後に残された課題であろう。七 トの癌発生の $80 \%$ は外的要因に，そしてその $90 \%$ は 化学発癌物質に起因するといわれている．薬物代謝酵素 は解毒酵素であるととすに，ほとえどの化学発癌物質の 活性化酵素でもあることを考えると興味深い.

稿を終るにあたり，このような執筆の機会を与えてくださっ た信州大学医学部細菌学教室の神尾好是助教授に感謝申し上げ ます.

1) A.E.M.McLean \& E.K.McLean : Biochem.J., 100, 564 (1966).

2) T.C.Campbell : 'Effects of dietary protein on drug metabolism', in "Nutrition and Drug Interrelations", ed. by J. N. Hathcock and J.Coon, Academic Press, New York, 1978, p. 409.

3) T. Nakajima \& A.Sato: Toxicol. Appl. Pharmacol. 50, 549 (1979).

4) T. Nakajima, Y. Koyama \& A.Sato: Biochem. Phar macol., 31, 1005 (1982).

5) T.F.Slater: Nature, 209, 36 (1966).

(中島民江*, 佐藤章夫**, *信州大学医学部衛生学教 室, $* *$ 山梨医科大学第一保健学教室)

\section{植物病原細菌へのトランスポゾンの導入}

\section{一汎用性キャリアプラスミドの開発により病原性遺伝子の解析に手がかり}

各種植物の根頭がん腫病の病徴であるクラウンゴール は, 病原細菌 Agrobacterium tumefaciens の Ti プラス ミドの一部 (T-DNA) が植物細胞の DNA に組み込ま れることによって生じるという，驚くべき事実が最近明 らかになった. そこに至るまでの一連の研究は, 他の植 物病原細菌プラスミドの研究の進展に大きな弾みをつけ
ることとなった。 この数年の間, Pseudomonas syringae pv. savastanoi のプラスミド pIAAl がオリーブ の枝に腫瘍を起こす原因となる IAA（インドール酢酸） の産生を支配することが証明され，さらに，いくつかの 菌種に拈いて，毒素産生能に関連すると推定されるプラ スミドや伝達性プラスミドの存在が 相次いで報告され 
た (1). このように, 植物病原細菌固有のプラスミドの機 能を解明寸る研究は, 確実に一つの流れになりつつある.

さて，植物病原細菌とプラスミドの関わりを考える場 合，無視できないもら一つの研究の流れがある. それ は, 植物病原細菌以外の細菌, たとえば大腸菌 (E. coli) や緑膿菌由来のプラスミドを植物病原細菌に導入し，そ の伝達能を利用して遺伝子解析を行ならという研究であ る. この研究は, E. coli と同じ腸内細菌科に属する Erwinia 属細菌において大きな成果が得られている.す なわち, Chatterjee らは, Erwinia amylovora および Er. chrysanthemi にプラスミド F'lac を導入してその Hfr 株を得, それと各種変異株との接合中断実験によ り, 病原性を含む各種遺伝子のクロモゾーム上の遺伝子 地図を作成することに成功した，與味深いことに，この 地図は，E. coli のそれと非常によく似たものであっ た

これに対し, 植物病原細菌の大勢を占めるPseudomonas や Xanthomonas 属細菌においては, Hfr が得 られないこともあり, Erwinia のよらな遺伝子地図はま だどの種においてもできていない，ただこれらの細菌 は, RP 4, RK 2 などの緑膿菌由来の P-1 群プラスミド を非常によく受容するので，それらを利用した遺伝子解 析が今後期待されている.

一方，遺伝子解析に利用できる “道具”として，最 近, 転移性 DNA, とりわけトランスポゾンがクローズ アップされてきた．これは，それ自身では複製能力をも たない DNA の断片で, 細胞内のいろいろのレプリコン に転移することによりはじめて複製される，そして，多 くの場合, 薬剤耐性の遺伝子をもち, かつ, それがレプ リコンに插入されたとき, 插入部位の遺伝子の形質発現 が抑制（ポーラー変異）される.このような性質から, 特定のレプリコンに薬剤耐性のマーカーを付与したり, 各種変異株を作出するなど細胞内遺伝子操作にトランス ポゾンを利用できることが示された ${ }^{(3)}$.

トランスポゾンをある細菌に導入するためには, 一般 に受容菌の中で複製できないか，あるいは，たやすく除 去されるトランスポゾンを運ぶレプリコン（キャリア） が必要である. 植物病原 Pseudomonas においては, こ のよらなキャリアがまだ見いだされていなかった。 キャ
リアとして有望な腸内細菌由来のプラスミドやファージ は, 一般に寄主範囲が狭いし, $40^{\circ} \mathrm{C}$ 前後の培養温度で容 易に細胞内から除去できる温度感受性プラスミドも, こ の温度では生育できない大部分の植物病原菌には利用で きないことも，この研究の進展を阻んでいた。

そこで，筆者らは Pseudomonas のトランスポゾン・ キャリアとして, プラスミド pAS $8 \mathrm{Tc}^{\mathrm{s}} r e p-1:: \operatorname{Tn} 7$ (以下 pAS 8 と略記) に着目し, 数種の細菌を受容菌と して用い検討した ${ }^{(4)}$. pAS 8 は, RP 4 と ColE1 を Eco RI 切断面で結合させ, さらに, それにストレプトマイ シンとトライメソプリムの耐性マーカー $\left(\mathrm{SM}^{\mathrm{r}}, \mathrm{TP}\right)$ を もつトランスポゾン Tn 7 を挿入してできた複合プラス ミドである，RP 4 は広い宿主範囲をもつが, ColE 1 は 狭く, Pseudomonas では複製されない. したがって, RP 4 の伝達能によりPseudomonas に導入された pAS 8 は, ColE 1 の複製不能により消失し, そのため Tn 7 のみが受容菌のゲノムに転移するのではないかと 推測された。

実験の結果は良好であった. E. coli AB 2463 (pAS 8) と Pseudomonas syringae pv. tabaci, P.s.phaseolicola および P.s. mori ${ }^{(5)}$ と接合させ, 選択培養を行なっ

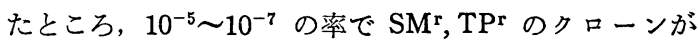
得られた. これらクローンは, RP4 のマーカーである カナマイシン (KM) の耐性を失っており, Tn 7 のみが 受容菌に転移したものと推定された. この Tn 7 の転移

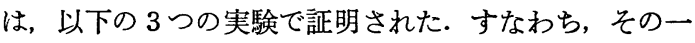
つは, P.s.tabaci BR 2 株のプラスミド pBPW $1^{(6)}$ への Tn 7 の転移が確認されたことである. pBPW 1 は約 30 Mdal の分子量をもつが， トランスコンジュガントのプ ラスミドの分子量は約 $39 \mathrm{Mdal}$ であり, Tn 7 の $9 \mathrm{Mdal}$ 分だけ増加していた.さらに, この pBPW $1:$ : Tn 7 を 制限酵素 Hind III で切断すると, Tn 7 が 3 個所で切ら れるため，2つの断片が明瞭にアガロースゲル電気泳動 により検出された. 二つ目の証拠として, この実験で得 られた多くのトランスコンジュガント $\mathrm{pBPW} 1:: \operatorname{Tn} 7$ のいくつかが, pBPW 1 の機能の一つである伝達能を衰 失していたことである.このことは, pBPW 1 の伝達能 を発現させる tra オペロンのどこかに Tn 7 が組み込ま れたことを意味する.な找，多くのクローンの解析によ 
り、この遺伝子群の执およその位置を明らかにすること ができた.

三点目は, P.s.phaseolicola (chr : : Tn 7) に RP 1 ts を導入したトランスコンジュガントとE. coli SK 1592 との接合実験により確認された。すなわち，混合培養液 を $\mathrm{SM}$ および $\mathrm{KM}$ で選択すると， $\mathrm{SM}^{\mathrm{r}}$ のクローンが $\mathrm{KM}^{\mathrm{r}}$ の $10^{-3} \sim 10^{-4}$ の率で得られた. このことは, RP 1 ts が SK 1592 に移行する際, 低率ながら P.s.phaseolicola のクロモゾーム上の Tn 7 が RP 1 ts に移転し, RP 1 ts : : Tn 7 となって E. coli に移行したことを示し ている. それは前述の Hind III による切断後の電気泳 動像によっても確認された. 以上によりPseudomonas への Tn 7 の転移が確実となった.

今回見いだされたトランスポゾン導入のためのキャリ ア・プラスミドは，RP 4 による接合卮達の寄主範囲に

\section{力二の味}

\section{一一ミッションテストによる呈味成分の解析}

水産物には美味なるのが多い. 特に, エビ・カ二類, 貝類,イカ類などの例にみられるように，無筒椎動物に 味が濃く美味なものが多い, 魚類では, タイ類, カレ イ・ヒラメ類, タラ類などの白身魚は味が淡白であるの に対し，マグロ・カッオ類などの赤身魚は一般に味が濃 厚である.

これらの美味な水産物の呈味成分を解明しょうとする 研究は，水産物を多食するわが国で古くから行なわれ， アミノ酸, ヌクレオチド, 有機酸など, 種々の成分が呈 味物質として提唱されてきた. しかし，従来の研究は純 品の味とその物質の含量の多寡から呈味効果を推測した ものが多く，多数の成分によって構成される複雑な味 に，個々の成分がどのように関わっているかを詳しく調 ベた例は，おそらく 1964 年に発表された小俣(1)のウ二 の研究が初めてであろう. 彼はウニ（食用としているの はその生殖巣) のらち最も美味なバフンウニを選び, 遊 離アミノ酸, 各種有機塩基, ヌクレオチドと関連物質, 有機酸, 糖などのエキス成分を詳細に分析した後, その 組成どおりの合成エキスを作り，この味が天然のウニェ キスによく似ていることを確かめてから，オミッショテ
入り，かつ ColE 1 の複製が不能なものであれば，どの 細菌においても利用されらる. したがって, 今後, 多く の植物病原細菌に拈いてトランスポゾンの導入が試みら れよう.そしてそれによりこれまで困難視されていた 各種植物病原細菌, とくにPseudomonas のプラスミド の機能解明やクロモゾームの遺伝子解析の研究が進展す るものと期待される.

1) 佐藤 守: 植物防疫, 35, 390 (1981).

2) A. K. Chatterjee : Proc. 4 th. Int. Conf. Plant Path. Bact. Angers., 3 (1978).

3) N. Kleckner, J. Roth \& D. Bostein : J. Mol. Btol., 116, 125 (1977).

4) M. Sato, B. J. Staskawicz, N. J. Panopoulos, S. Peters \& M. Honma : Plasmid, 6, 325 (1981).

5) M. Sato, B. J.Staskawicz \& N. J.Panopoulos: Ann. Phytopath. Soc. Japan, 48, 27 (1982).

6) B. J.Staskawicz, M. Sato \& N. J. Panopoulos: Phytopathology, 71, 257 (1981).

（佐 藤 守, 農林水産省虫糸試験場）

スト (omission test) を行なった.すなわち, 合成エキス から成分群または単一成分を除いたときに味がうう変わ るかを味覚試験で調べることにより，味の構成要素とし ての各成分の役割を追求し, Gly や Ala が甘味に寄与し ていること, Glu や IMP, GMP などのヌクレオチドが うま味に関与していること，それまで水産物の呈味成分 としては顧みられなかった Val と Met がウ二特有の味 の発現に重要な成分であることなどを明らかにした。

これと同じ研究方法を次々に美味な水産物に適用して ゆけば，それぞれに特有な持ち味を解明できるわけであ るが，この種の研究がそれ以前になかったのは，(1)エキ ス中の多数の成分を迅速かつ精度よく分析することが困 難であったことや，(2)訓練されたパネルを用意し，単調 な官能検查を何度も何度も根気よく絽り返すことが相当 面倒なこと，などによると考えられる．(1)については， 自動分析計の発達した今日では考えられないことである が, 普通のアミノ酸の分析すら容易でなかった当時のこ とを御存知の方には納得していただけるであろら. 分析 法の進んだ今日，(1)の問題はほぼ解決したが，(2)は避け て通れない障害として残っている. 
さて, 話を本題のカニの呈味成分に移そう. 食用種と してズワイガニ，タラバガニ，ケガニ，ガザミなどいる いろあるが，カ二は誰にも好まれる美味な水産物の筆頭 に挙げられる。しかし，この海の幸も他にもれず年々漁 獲量が減少し，今ではめったに口にできないほど高価に なってしまった．カニ足とかカニ棒と称するイミテーシ ョンが大ヒット商品になってかまぼこ業者を喜ばせてい るのは, おいしいカ二肉を安く食べたいという庶民の願 いの現われであろう．ところが，このカニが最近まで呈 味成分の研究対象になっていなかったのである，水産食 品化学者の怠慢といわれても返す言葉がない，そこで， 筆者らの研究室では, 最も美味とされるズワイガニ（マ ッバガニともいわれる）の雄を選び，オミッションテス トにより募熟肉の味の構成要素を調べることにした(2).

まず，エキス調製法を吟味したところ，窒素成分の抽 出能や風味からみて，熱水抽出液にエタノールを $80 \%$ 濃度になるように加えて除タンパクする方法が最適と判 断されたので，この方法で調製したエキスにつきアミ， 酸（I ），核酸関連物質(II)，四級アンモニウム塩基 (III)，糖 $(N)$ ，有機酸 $(V)$ ，無機成分 $(U)$ を分析した。 測定された成分を重量べースで合計するとエキス乾物量 の $92 \%$ に，窒素ベースで合計すると $98 \%$ にそれぞれ 達した．この数值から，エキス中の主要成分を注添完全 に分析できたと考えられたので，分析值を基にして 44

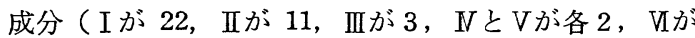
4 成分）からなる合成エキスを作り， 3 点識別法による 官能検查を行なったそその結果を要約すると次のように なる。

(1)合成エキスは天然エキスに比べてこくとまろみに 欠けるきらいがあるが，天然エキスの味がよく再現され でり，カニエキスであることがすぐわかる. (2) I， II， Иのいずれを欠いても呈味が大きく変わるが，III， $\mathrm{N}$ ，Vを除いても明瞭な味の差は感じられない。（3Ｉの らち呈味効果の認められたものは Gly, Ala， Glu，Arg で, Gly を除くと甘味のほかにうを味がかなり低下し， Ala を除くと甘味がいくぶん落ちる．また，Gluを欠く とうま味が著しく低下し，カ二様の味と甘味がかなり弱 まる. Gly（肉 $100 \mathrm{~g}$ 中 $623 \mathrm{mg}$ ) に次いで多量に存在す る $\mathrm{Arg}$ (同 $579 \mathrm{mg}$ ) はカ二特有の味に重要で, これを
除くと味が全体的に弱まるとともに，カニらしい味も弱 くなる. (4) IIでは AMP か GMP のいずれかが欠けると うま味が多少落ち，両成分を同時に抜くとうま味の著し い低下を招く．CMP の呈味作用ははっきりしなかった がそそれを除いた合成エキスはパネルにより識別された ので，何らかの効果があるらしい，(5) Иでは， $\mathrm{Na}^{+}$と $\mathrm{Cl}^{-}$を欠いたときの味の変化はきわめて激しく，前者で は甘味とらま味が著しく低下してカニ様の味はまったく 消失し，後者では味がほとんど消失するほどである， $\mathrm{K}^{+}$ を欠くと亦っぽい味になるが，カ二様は味はいくらか残 る. $\mathrm{PO}_{4}{ }^{3-}$ を抜くと, 塩味, 甘味, うま味がやや弱くなる.

以上のオミッションテストで, 上記 11 成分が呈味物 質として浮かび上ったが，念のためこの 11 成分より成 る合成エキスに無効と判定された成分群または単一成分 を加えて味の変化を調べるアディションテスト（addition test）を行なったところ,オミッションテストでは 無効と判定されたベタイン (Bet) に，甘味とうま味のほ か水産物特有のフレーバーを付与する役割があるらしい といらことがわかった. かくしてカニの呈味物質として 12 成分を同定したが，12 成分だけでカニの味をかなり よく再現できるものの，44 成分の 合成エキスに比べる と味の強さは $80 \%$ 程度であった。

これらの結果を総合すると次のようになる. カニの基 本的な味は Gly, Glu, Arg, $\mathrm{AMP}, \mathrm{GMP}, \mathrm{Na}^{+}, \mathrm{Cl}^{-}$の 7 成分で構成される。これに $\mathrm{Ala}, \mathrm{Bet}, \mathrm{K}^{+}, \mathrm{PO}_{4}{ }^{3-}$ など が加わって味が修飾され，増強される．他の成分は，そ れぞれ単一成分としては味にほとんど寄与しないが，全 体としてまとまると味の増強効果を発揮する。

このように, カ二の味の構成を一応解析することがで きたが，この一連の研究を通じて最も印象深かったこと は, $\mathrm{Na}^{+}$と $\mathrm{Cl}^{-}$を除くと合成エキスの味が激変し，カニ 特有の味が消失してしまうことであった，適量の食塩が 甘味を増強したり，苦味を減少させたりする作用のある ことはよく知られているところで，食品の呈味成分の研 究に無機成分が欠かせないことを改めて痛切感じさせ られた。

1）小俣 靖：日水誌，30，749（1964）

2) T. Hayashi et al.: J.Food Sci., 46, 479 (1981).

（鴻栄章二, 福家貪也, 東京大学農学部水産化学研究室） 


\section{酸性プロテイナーゼによるアンジオテンシンIの - His $^{6}-$ Pro $^{7}$-結合切断}

\section{菌類酵素による新反応発見から従来酵素の作用特巽性も整理}

タンパク質やペプチドの分子中にあって分子構造の安 定化に奇与(1)しているプロリンは，一般のアミノ酸とは 少々異なり，分子内環状構造をもつイミノ酸である. ᄂ たがって，プロリンはタンパク質，ペプチドの中では通 常のアミノ酸のよらにペプチド結合 (I)ではなく，イミ ノペプチド結合（II）によって結合している.そのため

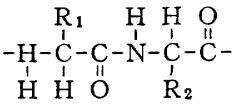<smiles>[R4]C(NC)C(=O)N(CC)C(CC)C(C)=O</smiles>

(II)
に, タンパク質, ペプチド中の -X-Pro-結合 $(\mathrm{X}=$ アミ ノ酸）は各種のタンパク分解酵素に対して著しい抵抗性 を示す. とはいうものの, -X-Pro- 結合を（1)〜 (3) 式のように加水分解するエキソペプチダーゼがいくつか 知られている.（1）はプロリンジペプチダーゼ（EC 3.4. 13. 9), ( 2 )はアミノペプチダーゼ $\mathrm{P}(\mathrm{EC}$ 3.4.11.9, アミ ノアシルプロリンアミノペプチダーゼともいら), ( 3 )は セリンカルボキシペプチダーゼ（EC 3.4.16.1)である.

$$
\begin{aligned}
& \mathrm{X}-\text { Pro } \\
& \mathrm{x}-\text { Pro } \cdots . . . \\
& \cdots . . \mathrm{X}-\mathrm{Y} \stackrel{\downarrow}{-} \text { Pro }
\end{aligned}
$$

エンド型のプロテイナーゼでは, クロストリペイン (EC 3.4.22,8, クロストリジオペプチダーゼB）が，ア ミノ酸 11 残基からなるキニン系のペプチドであるメ チオニルーリジルーブラジキニン (Met-Lys-Arg ${ }^{3}-\mathrm{Pro}^{4}$ Pro-Gly-Phe-Ser-Pro-Phe ${ }^{10}$-Arg）の-Arg ${ }^{3}-\mathrm{Pro}^{4}-$ 結 合を $\mathrm{pH} 7.7$ で加水分解する(2)ことなどがわずかに知ら れているくらいである.

ごく最近, Aspergillus sojae, Scytalidium lignicolum (いずれも菌類)からのアスパルティック(酸性)プロテイ ナーゼが,アミノ酸 10 残基からなるアンジオテンシン I (プロアンジオテンシンともいら) 中の - $\mathrm{His}^{6}-\mathrm{Pro}^{7}-$ 結合 を酸性 $\mathrm{pH}$ 領域で特異的に加水分解することが明らか
になった(3). これは, ペプチドホルモン中の-His-Pro結合のプロテイナーゼによる切断が確認された最初の例 である.

アンジオテンシン I $(1.54 \mu \mathrm{mol})$ K A soiae アスパル ティックプロテイナーゼIを 1.20 nkatal 添加し, 酵素/ 基質 $(\mathrm{e} / \mathrm{s})$ の比を $1: 2,260 \mathrm{~mol} / \mathrm{mol}, \mathrm{pH} 3.0$ で 3 時間反 $\underset{\text { Asp-Arg -Val - Tyr - Ile - His }}{2} \underset{- \text { Pro-Phe }- \text { His - Leu }}{3}$

1

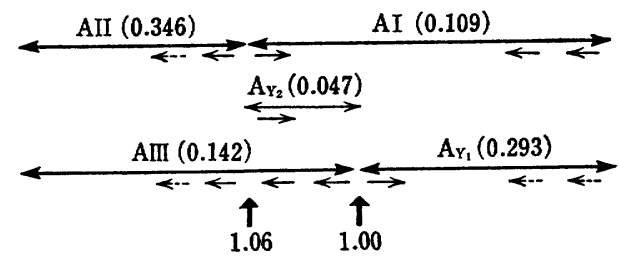

2
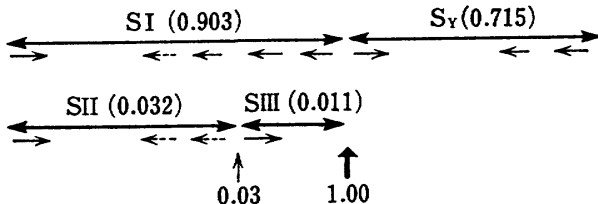

3

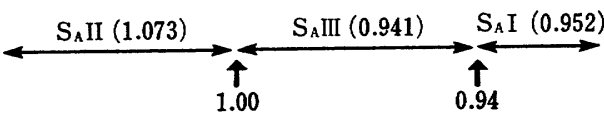

4

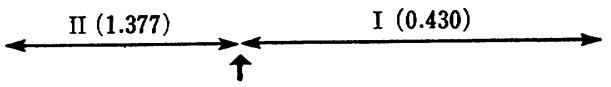

5

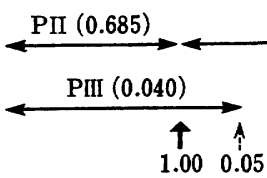

各種アスパルティック（酸性）プロティナーゼによるアンジ オテンシンIに対する特異性

↔ 回収ペプチドと（）内はその回収 $\mu \mathrm{mol}$ 数, $\rightarrow$ DNS 法によるN末端アミノ酸, ↔Penicillium アスパルティック ペブチダーゼによる遊離アミノ酸

$\uparrow$ 切断点と矢印 ( $\uparrow$ ) 下の数字は酵素切断の相対値

1 Aspergillus sojae フスハハルティックブロテイナーゼ

2 Scytalidium lignicolum アスパルティックプロテイナ 一ゼ B

3 Sc. lignicolum アスパルティックプロテイナーゼ A-1

4 Pycnoporus cocctneus アスパルティックプロテイナー せ $\mathrm{I}_{\mathrm{a}}$

5 ブタペプシン 
応させた，酵素反応生成物は濾紙電気泳動とペーパーク ロマトグラフィーにより分離した．この滤紙を乾燥後, ニンヒドリンを噴霧し， 3 つのスポット（A I, A II, A III）を得た. 次いで, パウリ試薬を噴霧し, 別に 2 つの スポット $\left(\mathrm{A}_{\mathrm{Y}_{1}}, \mathrm{~A}_{\mathrm{Y}_{2}}\right)$ を得た. ここで, パウリ試薬を噴 霧したことが, - $\mathrm{His}^{6}-\mathrm{Pro}^{7}$-結合切断による生成ぺプチド Pro $^{7}-\mathrm{Phe}-\mathrm{His}-\mathrm{Leu}^{10}$ を回収するという成功に導いた. 以 上の 5 つのペプチド画分を濾紙より切り取り，常法によ り，2枚のスライドグラスにはさんで水で抽出したのち， 凍結乾燥した. 凍結乾燥した精製ペプチドを 3 分し, (1)はアミノ酸分析, ( 2 )はダンシル(DNS) 化によるN 末端分析, (3) は筆者らの研究室で開発したPenicillium 酸性カルボキシペプチダーゼ(4)（蛋白質研究奖励会 ペプチド研究所ュード3502)によるC末端分析に供した.

S. lignicolum アスパルティックプロテイナーゼ Bは, $\mathrm{pH} 2.2, \mathrm{e} / \mathrm{s}=1 / 97, \mathrm{~mol} / \mathrm{mol}$ で, 3 時間反応させた.

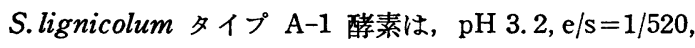
$\mathrm{mol} / \mathrm{mol}$ で 3 時間反応させた. P. coccineus アスパルテ イックプロテイナーゼ $\mathrm{I}_{\mathrm{a}}$ は $\mathrm{pH} 2.7, \mathrm{e} / \mathrm{s}=1 / 3,968, \mathrm{~mol} /$ $\mathrm{mol}$ で 6 時間反応させた. ブタペプシンは $\mathrm{pH} 2.0, \mathrm{e} / \mathrm{s}$ $=1 / 130, \mathrm{~mol} / \mathrm{mol}$ で 72 時間反応させた. 酵素反応後の 回収ペプチドを図に示す. A. sojae の酵素と S. lignicolum タイプ Bの酵素は-His ${ }^{6}-\mathrm{Pro}^{7}$ - 結合を明らかに切 断した. そのほかに，前者の酵素では-Tyr ${ }^{4}-\mathrm{Ile}^{5}$-結合の 切断が-His-Pro- 結合と同じ割合で起こった。他の $S$. lignicolum タイプ A-1 (酵素), P. coccineus 酵素, ブタ ペプシンでは-His ${ }^{6}-\mathrm{Pro}^{7}$-結合の切断は起こらなかった. また,アミノ酸 8 残基からなる活性型ホルモンであるア ンジオテンシンII（アンジオテンシン）に対して上記の 酵素を作用させてみると, 菌類の酵素はいずれも-Tyr ${ }^{4}-$ $\mathrm{Ile}^{5}$-結合を切断し，ブタペプシンでは $-\mathrm{Val}^{3}-\mathrm{Tyr}^{4}$ - 結合 の切断が起こった.
アンジオテンシン I 中の - $\mathrm{His}^{6}-\mathrm{Pro}^{7}$ - 結合を切断する A.sojae, S.lignicolum タイプ Bの両アスパルティック プロテイナーゼとも, インシュリン B 鎖の C 末端付近に あるーThr ${ }^{27}-\mathrm{Pro}^{28}$-結合を切断することができない.この ことは, Schechter と Berger による命名法(5)を用いて 説明すると, 上記両酵素とも $-\mathrm{His}^{6}-\mathrm{Pro}^{7}-$ 結合の切断が 行なわれるアンジオテンシン I では基質の切断点から C 末端側の 4 つ目のアミノ酸残基である $\mathrm{P}_{4}^{\prime}$ 位に疎水性ア ミノ酸が位置しているのに，インシュリンB鎖ならびに アンジオテンシンIIでは空位となっていて, 上述の条件 を満足していないためと考えられる.

以上のアスパルティック（酸性）プロテアーゼによる アンジオテンシンに対する特異性に関する知見 ${ }^{(3)}$ は, 動 物ペプシンと菌類アスパルティックプロテイナーゼとは まったく異なる特異性をるつことを示している．とし て, この知見は, 従来特異性について混乱しているアス パルティック（酸性）プロテイナーゼの作用特異性を 4 つのグループに分類することを可能とした.（1）は A. sojae 酵素と S.lignicolum のタイプ B酵素のグループ で, -His ${ }^{6}-\mathrm{Pro}^{7}$ - 結合と $-\mathrm{Tyr}^{4}-\mathrm{Ile}^{5}$ 結合を切断する の, (2) は S. lignicolum タイプ A-1 酵素のグルー プで, -Tyr ${ }^{4}-\mathrm{Ile}^{5}$ - 結合と - $\mathrm{Phe}^{8}-\mathrm{His}^{9}$ - 結合をともに切 断するもの, (3) は P. coccineus 酵素のグループで, -Tyr ${ }^{4}-\mathrm{Ile}^{5}$ - 結合にしか作用しないもの，（4）はブタぺ プシンのように - $\mathrm{Val}^{3}-\mathrm{Tyr}^{4}$ - 結合を主に切断し, -Tyr ${ }^{4}-$ Iles-結合をわずか切断するものである.

1) R.H.Pain : Nature, 290, 187 (1981).

2) W.M. Mitchell : Science, 162, 374 (1968).

3) E.Ichishima, E. Majima, M.Emi, K. Hayashi \& S. Murao: Agric. Bıol. Chem., 45 , 2391 (1981).

4) S. Yokoyama, A. Oobayashi, O.Tanabe \& E. Ichishima : Biochim. Biophys. Acta, 397, 443 (1975).

5) I. Schechter \& A. Berger: Biochem. Biophys. Res. Commun., 27, 157 (1967).

(一島 英治 東京農工大学農学部)

\section{Paecilomyces——多岐にわたる機能をもつかび}

\section{一広籍な有機物分解能など秘められた可能性を探る}

Paecilomyces は, 形態学的には Penicillium と類縁の かびであるが, ニロニーが緑色にならないこと, 胞子形 成器官（phialide）が先細りの特徽的な形を持つことな
どから, Penicillium と区別されている.この属は 1907 年 Bainier によって提唱されて以来, 数々の変遷を経 て, 1957 年 Brown と Smith ${ }^{(1)}$ によって 25 の種から 
なる属として体系づけられ, 1974 年 Samson(2) によっ てさらに分類に関する詳細な報告がなされている．

Paecilomyces 属かびの分離源は, 各種の土壌をはじ め, 堆肥, サイレージ, 海水, 木, 紙, 織物, 革, 昆 虫, ジェット燃料, フォルマリン漬標本など多岐にわた っており，この事実は，Paecilomyces が広範な有機物分 解能を有することを示唆している. 実際, これまでジュ 一ト㵶維や紙, メタノール, 蟻酸, プラスチック,ケロ シンなどの分解について報告がある，また，このかびの 代謝産物や利用に関する研究としては, フィンランドで 開発された亜硫酸パルプ廃液利用の pekiloprotein と呼 ばれる SCP 生産や, 我が国の竹内らによって発見され た抗生物質 variotin のように実用化に至ったものを はじめ, セファロスポリン系化合物, 抗ウイルス性の paecilomycerol, 抗真菌性の novalichin などの抗生物質 生産, 耐酸性プロテアーゼ, アミラーゼ, デキストラナ ーゼ, セルラーゼ, キシラナーゼなどの酵素, trans-Lepoxysuccinic acid, byssochamic acid および phenolpicolinic acid の生成, ヒマワリ種子粕からの SCP 生 産, ステロイドの転換, 鉄の還元などが主なものとして 挙げられる.

筆者らのこのかびとの出会いは, 8 年ほど前, 微生物 による非糖質炭素源の利用を目的に，それまで研究例の 少なかったかびを対象として，酢酸からの有用代謝産物 を検索し, 北大応用菌学教室保存の 30 属約 200 株の中 から,リンゴ酸生成能の高いPaecilomyces varioti (variotii）を見いだしたことに始まる．その後このかびの 発酵能を深く追求するにつれて, Paecilomyces という かびが，種々の特異的な性質と機能を併わせ持っている ことを痛感するようになった。

本稿では, 筆者らのたずさわった研究の中から,Paecilomyces の持つ多機能性について紹介してみたい.

揮発酸およびアルコールからのリンゴ酸生成 ${ }^{(3,4)}$ : 筆者らが見いだしたP. varioti は, 酢酸 $3 \%$ の培地で （以降, 基質としての揮発酸はすべててルシウム塩, 濃 度は遊離酸としての重量\%で示してある)，わずか 2 日 間の培養で対始基質 $40 \%$ を越える収率でリンゴ酸を生 成したが,ささらにプロピオン酸, 酪酸, エタノールなど からも高収率でリンゴ酸を生成する能力を持っている.
また，基質濃度を，酢酸では 10\%，プロピオン酸，酪 酸, エタノールでは 4〜 5\% と，このような基質にして はかなり高濃度と考えられる值にしても, 最終的なリン ゴ酸収率はいずれる $40 \%$ 以上に達し, 最高はエタノー ルからの約 $70 \%$ であった.これまで, 揮発酸からのリ ンゴ酸生成は報告がなく, 特にプロピオン酸は保存料と して食品添加物に指定されている程で，これを基質とし て微生物の有用代謝産物を得た例は，筆者ら ${ }^{(5)}$ がすでに 報告した Corynebacterium sp. によるピルビン酸生成 があるのみと思われる。

揮発酸の抗菌力と Paecilomyces の資化能：酢酸や プロピオン酸からのリンゴ酸生成に対する培地成分を検 討中, 酢酸を炭素源としたときには, $\mathrm{CaCO}_{3}$ 添加の有無 にかかわらずリンゴ酸が生成されるのに対し，プロピオ ン酸では, $\mathrm{CaCO}_{3}$ を添加しない限りリンゴ酸は生成さ れなかった．この原因を調べたところ， $\mathrm{CaCO}_{3}$ を加えな い場合には, 培地中の $\mathrm{KH}_{2} \mathrm{PO}_{4}$ が基質の $\mathrm{Ca}$ と反応す ることにより，酢酸またはプロピオン酸が一部遊離し， そのような条件下ではプロピオン酸が代謝阻害をひき起 こす，と考えられる結果を得た，揮発酸の抗菌力は，従 来その非解離分子にあるとされているが, 揮発酸塩自体 に対し高い資化能を持つ菌について調べた例はない。そ こで，3\% の酢酸カルシウム拉よびプロピオン酸カルシ ウム溶液の $\mathrm{pH}$ を, 培養開始時あるいは培養中に酸性側 に調整して培養を試みたところ，酢酸では $\mathrm{pH} 5$ 以下， プロピオン酸では $\mathrm{pH} 6$ 以下でリンゴ酸生成が阻害さ れ，菌の生育能も失われていた。 またここ場合には培 養液の $260 \mathrm{~nm}$ における吸光度が著しく増加した.これ らの結果から, 揮発酸塩に高い資化能を持つ菌株に対し てもその酸の非解離分子が抗菌力を現わすこと，その機 作は膜に対する不可逆的傷害であることなどが示され た.

半連続的なリンゴ酸発酵：リンゴ酸発酵の諸条件の 検討に用いた P. varioti AHU 9417 株は, 炭素源のみを 含む脱塩水溶液からも 7 〜 10 日の培坫で基本培地より もむしろ高い収率でリンゴ酸を生成できることを見いだ した. グルコースからのグルコン酸, フマル酸からのリ ンゴ酸のように, 単一酵素による反応で生成されるもの は別として，後に述べるように，多くの酵素が関与する 
一連の反応によって生ずる産物が，このように基質だけ を含む水溶液中において高収率で生成されることは興味 深い.この特性はまた, 連続培養や基質を半連続的に添 加する fed-batch 法などを適用できることを示してい る. 実際, fed-batch 法では, $50 \mathrm{ml}$ の培養液を含む振盪 フラスコに対し，1 日おきに酢酸を $2 \mathrm{~g}$ ずつ 6 回添加し た 2 週間の培養を通じて，添加物質に対し常に $50 \%$ を 越える収率でリンゴ酸が生成され続け，また 2 日扣きに $1.5 \mathrm{~g}$ のプロピオン酸を添加した場合にも, $50 \%$ 近い収 率が得られた.

リンゴ酸の生成経路： 供試菌株はグリオキシル酸回 路によって酢酸およびプロピオン酸をリンゴ酸へと転換 することを明らかにし，すでに報告した ${ }^{(6)}$ が，さらに酪 酸やエタノールからの生成にもこの回路が関与すること を示す結果を得た (4). グリオキシル酸回路は, C 2 化合 物が TCA 回路による脱炭酸を回避して生合成素材を供 給する系としての生理的意義を持っている．本菌におい ては，その回路で生ずるコハク酸が，フマル酸を経て速 やかにリンゴ酸へと転換されることにより，リンゴ酸発 酵が成立するものと考えられる。

転換発酵への利用: P. varioti AHU 9417 の生酸経 路の検討中に，このかびが高いフマラーゼ活性を持つこ とを見いだした。そこで，筆者らの教室ですでに開発さ れている転换発酵法を適用し，リンゴ酸発酵を試みた。 すなわち, Rhizopus arrhizusによるグルコースからのフ マル酸発酵に, P. variotiを最初から組合わせて培養した ところ, P. varioti 単独では約 45\% であった対始糖りン ゴ酸収率を，60\%を超えるまでに高めることができた。
糖化活性：上に述べたように，供試菌株はグルコー スを炭素源としてもリンゴ酸を生成するが，馬鈴薯，甘 薯, コーン, タピオカなどの澱粉を炭素源とした場合に も，これらを速やかに糖化し，リンゴ酸を生成すること がわかった.すなわち，5～10\% の硫粉を含も培地に少 量の前培養菌液を接種して， $37^{\circ} \mathrm{C}$ で 2 日間培養したと ころ, 初発洪粉当り $30 \%$ 前後の収率でリンゴ酸が生成 されまたこの発酵過程において一時的なグルニースの 生成蓄積がみられた。このことから，本菌がかなり高い 澱粉糖化力を持つことは明らかであり，関連酵素につい ての研究も深めつつある

以上，筆者らが研究過程に見いだしたPaecilomycesの 多岐にわたる機能を略述したが，この他にも， microcycle conidiation と呼ばれる, 分生子の発芽管上に新た な分生子形成が起こる特異な形態が振燙培養中にみられ ることなど,興味ある事実を見いだしており,このかびと の付合いはさらに深まるものと思われる，今後，かびの 各種機能の開発研究が進展する中でも, “Paecilomyces” は各所で顔を出すであろう.

1) A. H.S. Brown \& G.Smith : Trans. Brit. Mycol. Soc., 40, 17 (1957).

2) R. A.Samson: Studies in Mycology, 6, 1 (1974).

3) S. Takao, M.Tanida \& H. Kuwabara: J.Ferment. Technol., 56, 334 (1978).

4）谷田昌稔，星川泰俊，高尾彰一 : 昭和 55 年度酸工大会要 旨, p. 95 .

5) 高尾彰一, 谷田昌稔: 農化, 51, 239 (1977).

6) M. Tanida, Y. Hoshikawa \& S.Takao: J. Ferment. Technol., 59, 423 (1981).

7）横田 篤, 滝沢 悟, 谷田昌稔, 高尾彰一：昭和 55 年農 化東北·北海道支部合同講演会要旨, p. 21 .

（谷田昌稔，高尾彰一，北海道大学農学部応用菌学教室）

\section{施設栽培下における野菜の品質——アスコルビン酸を例として 一品種改良に加えて, きめ細かな栽培技術の工夫·道用が重要}

野菜の栽培技術の発達と, 一年を通じての新鮮な野菜 の需要増加といら点から, 近年では施設を利用した生食 野菜の周年栽培・出荷の体制が確立してきた。しかしな がらこのような生産の安定に伴って，一方では品質に 対しての関心が高まり, 多くの問題が各方面から出され てきている，特に，冬期の低温弱日照下で育てられた野 菜はアスコルビン酸含量が少ないなど，品質低下につい
ての指摘は多い，品質低下の防止法として最も有力なも のは品種改良によるものであろうが，一方では栽培技術 による効果も大いに期待されるところである. そこで筆 者は栽培条件と品質, 特にアスコルビン酸含量との関係 を明らかにすべく研究を行なってきている，

従来この方面の研究は, アスコルビン酸の化学分析法 の確立に続いて, 1940 年代のアメリカで盛んに行なわ 
れ，施肥や日照との関係が述べられている。日本におい ても同年代に菅原 ${ }^{(1)}$ が広範な研究を行なった。 しかしな がら，その後アメリカ，日本ではアスコルビン酸に関す る研究はあまり行なわれなくなり，現在ではソビェト連 邦，ブルガリアなどの共産圈諸国で育種も含めて研究が 行なわれているようである。このように栽培技術と品質 に関する研究は，現在のところあまり盛んではない，し かしながら，最近になり，日本でも野菜の新しい作型， 栽培技術が発達し，施設栽培が非常な勢いで增加するに 伴い，品質の問題が再び指摘されるようになってきた. 日本人は，食生活においてビタミンCの約 $70 \%$ を野菜 から摂っているといわれており，この意味からも野菜の 品質の研究は重要であり, 研究の進展が望をれている.

さて，施設園芸における野菜の品質低下の原因をさぐ るとき，最も問題となるのが光条件であろう，施設環境 の中で最も人為的にコントロールしにくいものがこの光 条件である．冬期は野外でも弱日照である，そのう光， ガラスやビニールなどでカバーして栽培するわけである から，夏の露地と比べたらはるかに弱い光のもとで栽培 していることになる. しゃ光処理などを施して光条件の 影響を調べてみると, 葉菜類は光合成器官そのものが可 食部位であるため，光条件による影響が直接的である。 すなわち，しゃ光処理によりアスコルビン酸，糖含量は 明らかに減少し，逆に硝酸態窒素含量は増加した．しか も，これらの成分は，天候，時刻などにより1日のらち でも容易に含量が変化する，したがって，冬季の葉菜類 の栽培では収穫時刻にも十分注意を払う必要があるので ある(2).

一方，果菜類への光条件の影響はどうであろうか．た とえばトマトの場合, 茎葉部への光条件よりも果実面へ の日射条件の影響が大きい.トマトの果実を寒冷しゃあ るいはアルミフォイルで包み，光の当らない果実を作っ てみると,アスコルビン酸含量は通常の $25 \%$ 以上減少 し，有機酸含量も明らかに減少する。つまり，まったく 光が当らないよらにして成熟した果実は, 栄養価は低 く，味もボヶているといらことである．逆に，光が当り にくい低段位の果実の果房周辺の葉を中胁に沿って切り 取り，果実によく光が当るようにして成熟させてみる と,もちろん葉面積は約 $1 / 2$ となり, 常識的には葉当り
の負担が増すわけであるが，できた果実はアスコルビン 酸含量が増加する場合が多く，糖，酸含量も増加する傾 向がみられた。つまり，味も栄養価も比較的良い果実が 得られたということである. しかもこの時, 葉面積の減 少による収量の減少はほとんどなかったのである，実際 の栽培場面では，冬期の施設栽培に抋いてトマトの果房 を通路側に向け，日射条件の悪い低位果房については， 1 番果が緑熟期になる頃に，果房上の $2 \sim 3$ 葉について 葉面積にして 3 4 割程度切り取って果実に光が十分届 くようにしてやれば，品質の良い果実が得られるものと 思われる(3).

ピーマンの場合はトマトよりさらに植接的で，一つの 果実の中でも日向部分と日陰部分ではアスコルビン酸含 量が異なり， 日向部分のほうが $30 \%$ 以上高い值を示 す.また，果実着生節の葉峘重要であり，この葉を摘除 すると, 果実のアスコルビン酸, 糖は $10 \%$ 以上も減少 してしまう。つまりピーマンの場合は，葉面積を減少さ せずに果実の受光体制をよくする必要があるということ である. 実験的にではあるが, アルミ蒸着フィルムでマ ルチングし，下からの反射光の効果をみたところ，約 10\%程度アスコルビン酸含量が増加するのを確かめてい る.ピーマンの場合は，このように葉面積は減らさずに 果実面へ十分光を当てる工夫が効果的である(4).

次に重要な栽培条件としては，施肥条件があげられ る. 施肥条件と一口に言らが，土性，土壤の物理性，土 壤水分などの違いによって品質への影響は大きく左右さ れてしまう．筆者は水耕栽培によってすべての実験を行 なっており，土の影響をなくし，再現性を高める努力を している．まず葉菜類であるが，尿素の葉面散布の効果 が高く、アスコルビン酸, 糖含量が増加した. また， 、 グネシウムが欠乏すると顕著に両成分が減少する傾向が 見られた．この結果から，葉菜類ではクロロフィル含量 とアスコルビン酸含量との間に深い関係のあることが推 察され，また実験的にも両者の相関関係が確認された ${ }^{(5)}$. 葉菜類を我耕栽培したとき, 培養液を標準の $1 / 4$ 程度の 低濃度にすると，生育は抑制されるがアスコルビン酸, 糖含量は顕著に増加した.これは, 光合成によって作られ た糖がタンパクなどを作る窒素同化なとに代謝されない ために葉中に蓄積したものと推察している. 栽培場面で 
は, 通常の標準培養液で栽培してきたものを収穫前 2 3 日間, 肥料のほとえど入っていない培養液下に置け ば,アスコルビン酸, 糖含量の高く，しかも硝酸態窒素 のごく少ない葉菜類が作れるわけである.

次に，果菜類への施肥条件の影響であるが，トマトに おいて, カリウムとリンの影響が大きく, 特にカリウム の増施により果実中のアスコルビン酸, 有機酸含量が増 加し, 食味も向上した. この効果は冬期の弱日照下で著 しいので, この時季のトマト栽培ではカリウムを増施し てやると品質向上が期待できる. 逆に, リンは多く施肥 すると茎葉が過繁茂となり，果実への日射条件が悪くな るためにアスコルビン酸含量が少なくなるものと思われ た. このように, 施肥, 水分管理によっては, 茥葉の過 繁茂を招き，間接的にせよ果実の品質低下をひき起こす ことが多いので, 冬季のトマト栽培では注意を払う必要 がある(6).

その他の環境要因として, 気温, 地温, 湿度, ガス条 件などが考えられるが，これらとの関係については機会 を改めて述べたい。ただ，この中で湿度については，実 験手法が困難なこともあり，研究が進んでいない．特に
夜間の湿度は物質の転流と深い関係があり，品質との関 わり合いは興味深いものがあり, 今後の研究進展が望ま れている.

以上，施設栽培下における野菜の品質について述べて きたが，「ハウス野菜はまずい」という批判を謙虚な気 持で受けとめる一方，周年を通じて消費者は新鮮な野菜 を望んでいるという事実に意を強くして, これからも品 質の良い，美味しいハウス野菜を作るように心がけるべ きであろう。それには前述のよ5に育種的な改良と栽培 技術の工夫を組み合わせて 考えれば，筆者は，おいし く，栄養価の劣らない施設野菜を作ることは，ある程度 は可能だと考えている.

1）菅原友太：“農・園芸作物のビタミンCに関する研究”，養 賢堂, 1957, p. 276 .

2) Y.Shinobara et al.: J.Japan. Soc. Hort. Sci., 50, 239 (1981).

3）篠原 温ら：昭和54年度園芸学会発表要旨, p. 194(1979).

4) 篠原 温ら: 昭和53年度園芸学会発表要旨, p. 238(1978).

5) 篠原 温ら：園学雑, 47, 63 (1978).

6) 篠原 温ら: 園学雑, 49,85 (1980).

(篠 原 温, 筑波大学農林学系)
プロフィル

一息 英治 (Eiji Ichishima) Vol 19 No.11， p. 694 参照

大野 雅二 (Masaji Ohno) 昭和 5 年 10 月 27 日生 $<$ 略歴>昭和 28 年北海道大学 理学部化学科卒業/同年同大学大学院理 学研究科 $/ 32$ 年イリノイ大学大学院 (フ ルブライト留学生), その後同大学および ハーバード大学 research fellow/36年東 $\nu$ (株)基礎研究所 $/ 52$ 年東京大学薬学部 教授, 現在にいたるく研究テーマと抱 負>生理活性物質の合成. 抗菌性および 制癌性物質として実際に使える役に立つ ものを創りたいく趣味〉碁, テニス

岡島 秀夫 (Hideo Okajima) 大正 13 年 2 月 22 日生 $<$ 略歴>昭和 22 年北海道 大学農学部農芸化学科卒業 /同年厚生省 東京衛生試験場 $/ 24$ 年東北大学農学研究 所助手 $/ 30$ 年同講師 $/ 43$ 年北海道大学農 学部助教授 (土壤学講座) $/ 45$ 年同教授, 現在にいたるく研究テーマと抱負〉土埣 肥沃度, 特に土壌の養水分供給能を定量
的に表示する道を求める目的で，土龔固

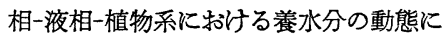
興味を持っているく趣味〉読書

岡西 昌則 (Masanori Okanish 1 ) 昭 和 5 年 2 月 26 日生 $<$ 略歴 $>$ 昭和 28 年東京 教育大学理学部生物学科卒業/同年万有 製薬(株)研究所勤務 $/ 34$ 年ブリストル万 有研究所勤務 $/ 38$ 年国立予防衛生研究所 抗生物質部勤務 $/ 51$ 年同抗生 物 質 部室 長, 現在にいたる.この間, カナダ・グ エルフ大学留学〈研究テーマと抱負〉 抗生物質はなぜどのようにして生産され るのか?（趣味〉みんなとわいわい酒を 领むこと，犬と一緒に走ること（犬名へ クター)

鴻策 章二 (Shoji Konosu) 昭和 3 年10月18日生 <略歴 > 昭和 26 年東京大学 農学部水産学科卒業／同年同大学農学部 助手 $/ 33$ 年同助教授 $/ 50$ 年同教授, 現在 にいたるく研究テーマと抱負〉水産物の エキス成分, 水産生物活性物質, プラン
クトンの化学と利用く趣味〉スポーッ （最近は専ら T V 観戦）

佐々木 椤 (Ken Sasaki) 昭和23年 12 月 20 日生 <略歷>昭和 47 年埼玉大学理 工学部生化学科卒業 $/ 52$ 年東北大学大学 院農学研究科博士課程修了/同年米国口 シントン州立大学生物化学研究所研究員 $/ 56$ 年埼玉大学理学部研究生 $/ 57$ 年カナ ダ・ブリティシュ・コロンビフ大学植物 学教室研究員く研究テーマと抱負〉植物 の発芽・生長などの生理現象を物理化学 的に解析することく趣味〉旅行, スポー ッ（特に空手）

佐藤 章夫 (Akio Sato) 昭和 13 年 5 月14日生<略歴 $>$ 昭和38年信州大学医学 部卒業 $/ 43$ 年同大学大学院医学研究科修 了/同年同大学医学部助手(衛生学) $/ 48$ 年 同助教授 $/ 57$ 年山梨医科大学教授（第 1 保健学), 現在にいたるく研究テーマと 抱負 $>$ 栄養と化学物質の毒性 (特に発癌 性）に興味を持っていますく趣味〉謡曲 